\title{
Comparative Study of Reproductive Traits in Gangetic Hairfin Anchovy, Setipinna phasa (Hamilton, 1822) from Estuarine and Freshwater Ecosystems
}

\author{
Brijesh Kumar Chaubey ${ }^{1}$, Farah Bano ${ }^{1}$, Mohammad Serajuddin ${ }^{1, *}$ (i)
}

${ }^{1}$ Fish Biology Research Lab, Department of Zoology, University of Lucknow, Lucknow-226007, Uttar Pradesh, India

\section{How to cite}

Chaubey, B.K., Bano, F., Serajuddin, M. (2021). Comparative Study of Reproductive Traits in Gangetic Hairfin Anchovy, Setipinna phasa (Hamilton, 1822) from Estuarine and Freshwater Ecosystems. Turkish Journal of Fisheries and Aquatic Sciences, 21, $179-189$. http://doi.org/10.4194/1303-2712-v21_4_03

\section{Article History}

Received 08 August 2020

Accepted 13 January 2021

First Online 14 January 2021

\section{Corresponding Author}

Tel.: +919415871277

E-mail: lu.fisheries@gmail.com

\author{
Keywords \\ Fecundity \\ Gonadosomatic index \\ River Ganga \\ Hooghly estuary
}

\begin{abstract}
The Gangetic hairfin anchovy, Setipinna phasa (Hamilton, 1822) were collected from river Ganga (Kanpur) and Hooghly estuary (Kolkata) to study the comparative reproductive traits (sex ratio, spawning season, gonado-somatic index, fecundity and egg diameter). Female outnumbered the male in the population of river Ganga but it was non-significant in the population of the estuary. Five maturity stages were identified in males and females of the fish of both ecosystems. Occurrence of multimodal (immature, maturing and mature) and uni-modal (matured) type of ova in the ovary of the fish of Hooghly estuary and river Ganga respectively and the values of gonado-somatic index confirmed the double and single spawning in a year in the fish in estuary and river respectively. The absolute fecundity was found to be higher in the fish of river Ganga compared to that of the estuary $(P<0.05)$. Linear and positive correlations between fecundity and the total length, body weight, ovary length and ovary weight were noted in the fish of both ecosystems $\left(R^{2}>0.90\right)$. The present study provides the comparative account of the reproductive and spawning strategies of $S$. phasa for the first time in favour of the proper management and conservation of the fish.
\end{abstract}

\section{Introduction}

The study of the reproductive cycle and fecundity is essential and fundamental for understanding the fish population dynamics to obtain a sustainable harvesting (Murua et al., 2003; Cao et al., 2009). The study of population characteristics and reproduction of the fish is considered to be important for the assessment of commercial potentialities of the fish stock, life history and its management, because management procedures rely entirely upon the reproductive potential of the fish (Doha, 1970; Froese, 2004; Morgan, 2008; Eyo et al., 2014). The study of the reproductive traits includes the knowledge of the size of the fish at first maturity, spawning, sex-ratio, duration of the reproductive season, gonado-somatic index (GSI), ova diameter and fecundity (Murua et al., 2003; De Carvalho et al., 2009; Fontoura et al., 2009). The reproductive study also helps to reveal the differences between the fish stocks of different ecosystems characterized by different environmental conditions (Begg, 1998) and the information so derived are considered to be useful for the artificial breeding of the fish to produce fry and fingerlings on demand (Kamanga et al., 2012). The size at first maturity and fecundity of the fish show an adaptive response to the ecological gradients to ensure the survival of the species to enhance individual fitness (Blanck \& Lamouroux, 2007; Guèye et al., 2012). 
Setipinna phasa is popularly known as Gangetic hairfin anchovy which belongs to the family Engrulidae and order Clupeiformes. The fish is carnivorous in nature; mainly subsist on the feeds available in column and surface of the water of the habitats. The fish, $S$. phasa is known to occur in the coasts of Bengal and Orrisa, entering estuaries and rivers through the tidal water. Among the various species of Setipinna, S. phasa has restricted distribution from the Ganges riverine system to the coastal waters of West Bengal (Jones \& Menon, 1952; Whitehead, 1972; Whitehead et al., 1988). Setipinna phasa is a pelagic fish which shows amphidromous and potamodromous migration and form one of the major fisheries along the north-east coast of India (Saigal et al., 1987). The species has been classified under 'Least Concern' category (IUCN, 2010). The fish is quite popular as a table fish and nutritious too and hence, considered as commercially important. In spite of the high demand of the fish no any commercial culture has been carried out so far because of the scanty information on the biology of this species. The abundance of the fish is dwindling because of reckless exploitation due to illegal fishing and the anthropogenic pollution of rivers and estuaries. The fish has been the object of very few studies despite its palatability and high consumer demand; Jones and Menon (1952) studied the life history, bionomics and fishery while maturity and fecundity were studied by Jhingran (1961).
The morphological variations discernible by multivariate analysis and anomalies in pectoral and pelvic fins have been reported by Gangan et al. (2016, 2018a, 2018b). Keeping in mind the paucity of information on the reproductive biology of $S$. phasa, the present study was undertaken on comparative examination of reproductive characteristics of $S$. phasa from two different ecosystems (river and estuary).

\section{Materials and Methods}

\section{Study Area}

The river Ganga emerges from the Gangotri glacier at Gomukh ( $30^{\circ} 36^{\prime} \mathrm{N} ; 79^{\circ} 04^{\prime} \mathrm{E}$ ) which is about $25.2 \%$ of the total freshwater resources of India. The river shows high fluctuations in the rate of water flow within the catchment area and the mean maximum rate of water flow of the river Ganga is $468.7 \times 109 \mathrm{~m}^{3}$ (Sarkar et al., 2012a). The two major distributaries of the river Ganga are Bhagirathi (India) and Padma (Bangladesh). The Bhagirathi flows west and south-west of Kolkata and is known as Hooghly branch and finally drains towards Bay of Bengal. The southern portion of the river is known as Hooghly estuary $\left(21^{\circ} 40^{\prime} \mathrm{N} ; 87^{\circ} 47^{\prime} \mathrm{E}\right)$ which is the first deltaic derivative of the river Ganga. The Hooghly estuary has a catchment area of 69,104 sq. km and well mixed with seawater due to its shallow depth of less

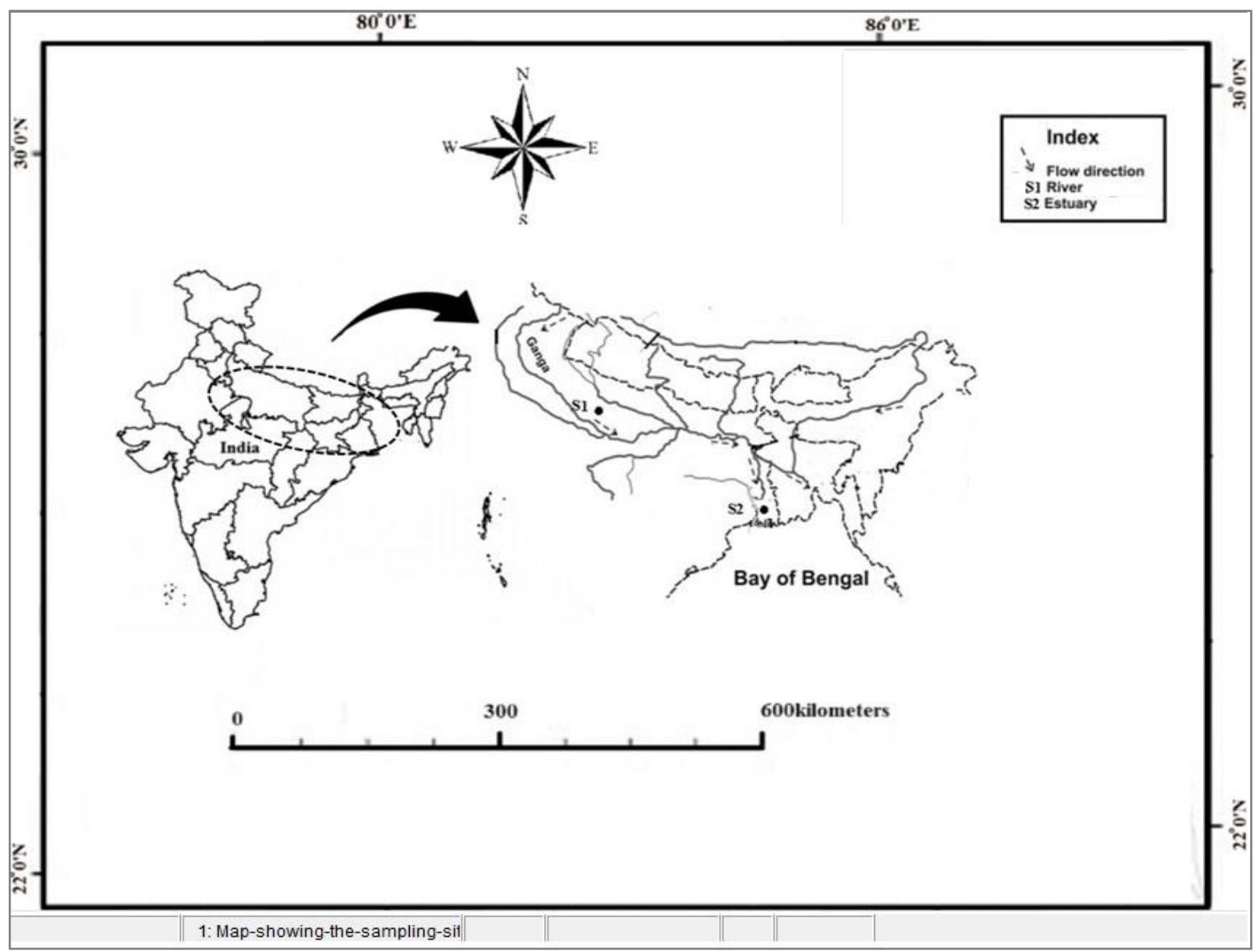

Figure 1. Map of the sampling sites, S1=river Ganga and S2=Hooghly estuary. 
than $6 \mathrm{~m}$ (Abbas \& Subramanian, 1984; Sadhuram et al., 2005). The distribution map of the sampling sites is given in Figure 1.

\section{Sampling}

A total of 1,023 (466 males of size ranged between 70-240 $\mathrm{mm}$ and 557 females of size ranged between 70 $250 \mathrm{~mm}$ ) individuals from river Ganga and 1,069 (511 males of size ranged between $60-320 \mathrm{~mm}$ and 558 females of size ranged between $60-340 \mathrm{~mm}$ ) individuals from Hooghly estuary were collected using small meshed (3-4.5 cm in size) cast and drag nets. The monthly sample, comprising 30-60 individuals of $S$. phasa, was procured from both the ecosystems during January-December 2017 and brought to the laboratory packed in ice.

The individuals of the fish were initially cleaned with distilled water and their total length ( $T L$ ) and eviscerated body weight (BW) were measured using a digital calliper and electronic balance sensitive to the nearest $0.1 \mathrm{~mm}$ and $0.1 \mathrm{~g}$ respectively. Sex of the fish was determined on the basis of different colouration of the pectoral and caudal fins, reddish swollen genital papilla, soft and bulging abdomen (Winn, 1958a \& b; Page, 1974). The weight of the cleaned gonads of the fish was measured using an electronic balance sensitive up to $0.001 \mathrm{~g}$. The ovaries of all the samples were preserved in $4 \%$ formaldehyde solution after recording their weight (OW) and length (OL).

\section{Maturity Stages}

The maturity stages were ascertained on the basis of the morphological structure of the gonads, space engaged by them in the abdominal cavity and the diameter of unspawned eggs (Nikolsky, 1963; Reddy 1979; Sarkar et al., 2019). Besides, the percentage of occurrence of the ripe individuals was determined during spawning season (Prasad et al., 2011; Sarkar et al., 2019). The gonadal maturation was studied under dissecting microscope, and categorized into one of the five stages of maturity as suggested by Brown-Peterson et al. (2011): I (immature), II (developing), III (spawning capable), IV (regressing) and V (regenerating). Intraovarian eggs were measured at different stages of maturity. The diameter of 40-50 ova per month was measured with the help of ocular micrometre using 8 x12.5 magnifications under a binocular dissecting microscope along the longest axis of ova as suggested by Clark (1934).

\section{Gonado-Somatic Index}

GSI of males and females of the fish of each month was computed to determine the gonadal development and frequency of spawning as per Afonso-Dias et al. (2005) using the formula:

\section{$\mathrm{GSI}=100 \times \mathrm{OW} / \mathrm{BW}$}

Where, OW is the fresh ovary weight and BW is the eviscerated body weight of fish

\section{Fecundity and Condition Factor}

The fecundity study was based on the examination of ripe gonads. The total weight of each ovary of all ripe female fish was taken and $100 \mathrm{mg}$ sub-samples of eggs were removed from the anterior, middle and posterior regions of each ovary. The number of ova present in subsamples was counted and the average number of subsamples was multiplied by the $\mathrm{OW}$ to calculate the absolute fecundity. Relative fecundities (number of ova in-unit TL, BW, OL and OW) were also recorded. Besides, the relationship of fecundity with various body dimensions, gonadal dimensions was also worked out using linear regression analysis. The condition factor $(\mathrm{K})$ was calculated using the formula as suggested by Nash et al. (2006):

$$
K=B W^{*} 100 / T L^{3}
$$

Where, BW = is the eviscerated body weight of fish in $\mathrm{g}$ and $\mathrm{TL}=$ total length of fish in $\mathrm{cm}$.

\section{Statistical Analysis}

A preliminary analysis of the homogeneity and normality of the data was checked using KolmogorovSmirnov tests and Levene test. Once the normality was rejected, the data were statistically analysed by the Wilcoxon signed-rank test (nonparametric t-test) to reveal significant differences in means of reproductive variables (condition factors and fecundity) between two locations. One-way ANOVA followed by Tukey's post hoc test was used to resolve the significance differences in the GSI among various months. Average value of GSI of the fish of two ecosystems was compared using t-test. The results of sex proportions were tested using the chisquare test. Data are presented as means \pm SD. All data were analyzed using SPSS (version 16.0). An error of probability level of less than $5 \%(P<0.05)$ and a confidence of $95 \%$ are considered as the fiducial level of significance.

\section{Results}

\section{Sex Ratio}

In the river Ganga, the overall male to female ratio (o': 9 ) of S. phasa was 1:2.29 which was significantly different from the expected ratio $\left(\sigma^{\top}: \rho=1: 1\right)$ of chisquare test $\left(\chi^{2}=4.159 ; d f=1 ; P<0.05\right)$. Females outnumbered the males in the riverine population of $S$. phasa throughout the year except for February and October. The details are given in Table 1. In the Hooghly 
Table 1. Monthly sex ratio of males and females of S. phasa collected from river Ganga and Hooghly estuary.

\begin{tabular}{|c|c|c|c|c|c|c|c|c|}
\hline \multirow{3}{*}{ Months } & \multicolumn{4}{|c|}{ River Ganga } & \multicolumn{4}{|c|}{ Hooghly estuary } \\
\hline & \multicolumn{2}{|c|}{ Abundance } & \multirow{2}{*}{$\begin{array}{c}\text { Sex ratio } \\
\left(\sigma^{x}: 9\right)\end{array}$} & \multirow[t]{2}{*}{$\chi^{2}$} & \multicolumn{2}{|c|}{ Abundance } & \multirow{2}{*}{$\begin{array}{c}\text { Sex ratio } \\
\left(\sigma^{x}: 9\right)\end{array}$} & \multirow[t]{2}{*}{$\chi^{2}$} \\
\hline & $\sigma^{\pi}$ & 우 & & & $\sigma^{\prime}$ & ㅇ & & \\
\hline Jan & 39 & 39 & $1: 1.00$ & 0.000 & 37 & 39 & $1: 1.28$ & 0.254 \\
\hline Feb & 41 & 38 & $1: 0.73$ & 0.485 & 44 & 41 & 1:0.79 & 3.365 \\
\hline Mar & 43 & 54 & $1: 1.85$ & 3.587 & 46 & 51 & 1:1.31 & 0.688 \\
\hline Apr & 46 & 61 & $1: 1.94$ & $5.330 *$ & 46 & 53 & $1: 4.44$ & 1.298 \\
\hline May & 32 & 43 & $1: 6.52$ & $17.452^{*}$ & 42 & 39 & 1:0.75 & 0.438 \\
\hline Jun & 36 & 48 & $1: 3.00$ & $8.000 *$ & 40 & 44 & $1: 1.40$ & 0.686 \\
\hline Jul & 34 & 41 & $1: 2.75$ & $4.176^{*}$ & 33 & 37 & $1: 2.33$ & 1.905 \\
\hline Aug & 37 & 46 & $1: 2.29$ & $4.159^{*}$ & 39 & 43 & $1: 1.44$ & 0.752 \\
\hline Sep & 38 & 44 & $1: 1.75$ & 1.768 & 42 & 46 & $1: 1.33$ & 0.583 \\
\hline Oct & 44 & 43 & 1:0.93 & 0.037 & 50 & 57 & $1: 1.35$ & 1.066 \\
\hline Nov & 34 & 38 & $1: 2.00$ & 1.500 & 48 & 52 & 1.1.22 & 0.404 \\
\hline Dec & 42 & 62 & $1: 2.66$ & $11.458^{*}$ & 44 & 56 & $1: 1.86$ & $3.956^{*}$ \\
\hline Total & 466 & 557 & $1: 2.29$ & $4.159^{*}$ & 511 & 558 & 1:1.38 & 1.071 \\
\hline
\end{tabular}

$\sigma^{2}=$ males, $q=$ females, $\chi^{2}=$ chi-square value

*Significant values at the $5 \%$ level

estuary, the overall male to female ratio ( $\left.\sigma^{x}: \$=1: 1.38\right)$ was not significantly different from the hypothetical ratio of $\sigma^{x}: Q=1: 1$ except during December as revealed by chi-square test $\left(\chi^{2}=1.071 ; \mathrm{df}=1 ; \mathrm{P}>0.05\right.$; Table 1$)$. The percentage of females was high in Hooghly estuary during all the months except for February and May.

\section{Maturity and Gonadosomatic Index}

The maturity stages of gonadal development can be distinguished as: immature, developing, spawning capable, regressing and regenerating (Table 2). The details of the occurrence of the various maturity stages of the fish of both the ecosystems in different months are indicated in Figure 2. The spawning period of $S$. phasa ranged only once in a year from February to April in river Ganga, and high values of GSI were also synchronized during this period in both the sexes, which indicated the full development of their gonads (stage III). But in the same fish, the spawning was observed twice in Hooghly estuary where the ripe gonad (stage III) and high values of GSI were recorded during the periods between April-June and September-November (Figure 3). Overall, the average value of GSI in both the sexes was higher during the breeding season in both ecosystems, suggested peak spawning time of S. phasa. Monthly GSI values of both males and females of both ecosystems were significantly different (ANOVA, Tukey's post hoc test, $P<0.05)$ except during NovemberDecember in both the sexes of river Ganga (ANOVA, Tukey's post hoc test, $P>0.05$ ). The average value of GSI of the fish of two ecosystems was significantly different (t-test, $\mathrm{P}<0.01$ ).

\section{Oocyte Diameter}

The frequency distribution of ova diameter measurements from a ripe ovary of $S$. phasa collected from Hooghly estuary showed that it was multimodal type having three groups of ova (immature, maturing and mature) which indicated that the fish spawns more than once in a year. The size of ova ranged between 0.30-1.19 $\mathrm{mm}$ and fully matured and ripe eggs (diameter 0.80-1.19 mm) were recorded during May and November in Hooghly estuary. However, S. phasa procured from Ganga River was unimodal type (one type of egg) and the size of ova ranged between 0.26-1.05 $\mathrm{mm}$. Fully matured and ripe eggs (diameters 0.76-1.05 $\mathrm{mm}$ ) were recorded during March in river Ganga (Figure 4).

\section{Fecundity and Condition Factor}

The absolute fecundity in the specimens of $S$. phasa of the river Ganga varied between 3,600-24,000 with an average value of $10254 \pm 0.34$ while it ranged between $3,100-20,100$ in the fish of estuary with an average value being $10111 \pm 0.57$ which was found to be significantly different $(P<0.001)$ as revealed by Wilcoxon signed-rank test (nonparametric t-test) between the two sampling sites. The recorded average condition factor of the combined male and female ranged between $0.42-0.51$ and $0.62-0.81$ with the average value being $0.47 \pm 0.02$ and $0.89 \pm 0.63$ in S. phasa of the river Ganga and Hooghly estuary respectively, which was significantly different $(P<0.001)$ as depicted by Wilcoxon signed-rank test (Figure 3 ).

Relative fecundities showed linear and positive correlation $\left(R^{2}>0.90\right)$ for $T L, B W, O L$ and $O W$ of both the ecosystems, which were found to be significantly different $(P<0.001)$ for $T L, B W$ and $O W$ while nonsignificant for OL between the populations (Table 3).

\section{Discussion}

Sex ratio determinates the reproductive potential of a fish population that aid in the assessment of the reproductive biomass and fecundity of the total population (Marshall et al., 1998, 2006). In the present study, the biased sex ratio was observed where females 
Table 2. Criteria used for the determination of maturity stages of $S$. phasa collected from river Ganga and Hooghly estuary.

\begin{tabular}{|c|c|c|}
\hline Stage & Ovaries & Testes \\
\hline I (Immature) & $\begin{array}{l}\text { Ovaries small, thin and white in colour. Eggs very minute } \\
\text { and distinct only under microscope. }\end{array}$ & $\begin{array}{l}\text { Testes small, slightly elongated, distinguished } \\
\text { microscopically Vasdeference thin }\end{array}$ \\
\hline II (Developing) & $\begin{array}{l}\text { Ovaries yellow in colour, granular in consistency, ova } \\
\text { visible to the naked eye. Oviduct reduced. }\end{array}$ & $\begin{array}{l}\text { Testes elongate, white and opaque. } \\
\text { Vasdeferentia wide but reduced. }\end{array}$ \\
\hline $\begin{array}{l}\text { III (Spawning } \\
\text { capable) }\end{array}$ & $\begin{array}{c}\text { Ovaries yellow in colour elongated occupying whole-body } \\
\text { cavity. Blood vessels visible over the surface of the ovaries. } \\
\text { Ova extruded on light pressure, eggs were opaque and } \\
\text { distinct. }\end{array}$ & $\begin{array}{l}\text { Testes creamy white or reddish white in colour } \\
\text { occupying more than half of the body cavity. } \\
\text { Viscous fluid oozes out from cut ends. }\end{array}$ \\
\hline IV (Regressing) & $\begin{array}{c}\text { Ovaries yellow, enclosing the intestine by lateral } \\
\text { extension. Oviduct reduced. }\end{array}$ & $\begin{array}{l}\text { Testes elongated reddish or creamy white in } \\
\text { colour, Vasdeferens not discernible. }\end{array}$ \\
\hline V (Regenerating) & $\begin{array}{l}\text { Ovaries flaccid contracted and usually empty. The ovary } \\
\text { has few remnants of mature ova in recent spawned fish. } \\
\text { Weight reduced. }\end{array}$ & $\begin{array}{c}\text { Testes white, weight reduced. No milting on } \\
\text { pressure. }\end{array}$ \\
\hline
\end{tabular}

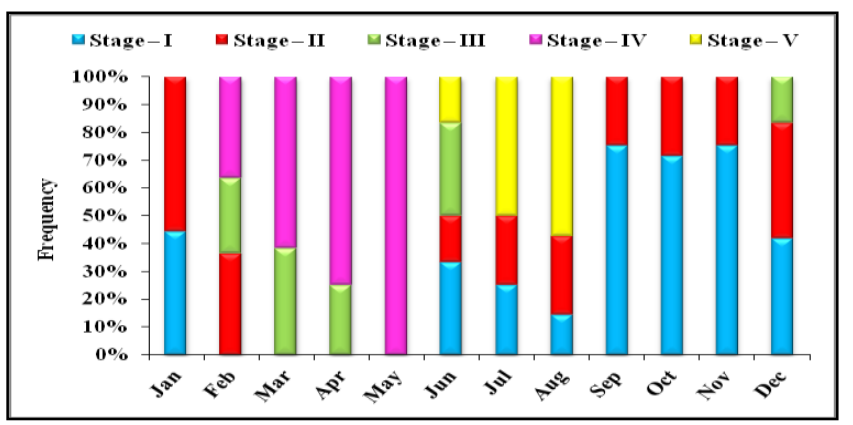

A

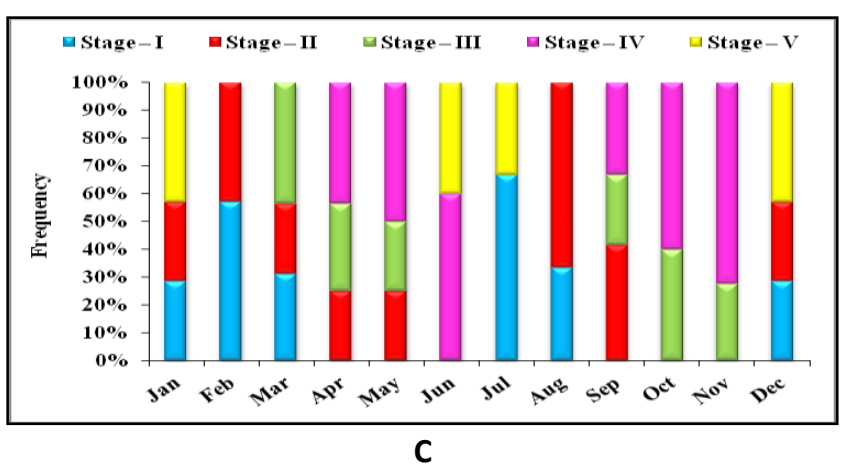

Figure 2. Maturity stages of $S$. phasa in different months collected from river Ganga ((A) males and (B) females) and Hooghly estuary ((C) males and (D) females).

dominated the males throughout the year in the riverine population of S. phasa except for February and October, while in Hooghly estuary; the overall male to female sex ratio was not significantly different from the hypothetical sex ratio except during December. Tsikliras and Koutrakis (2013) reported the female-biased population in the Sardina pilchardus and pointed out that the unequal sex ratio is natural in fish populations. Several researchers (Kabir et al., 1998; Corrêa et al., 2005; Deshmukh et al., 2010; Roomiani et al., 2014; Lopes et al., 2018) also reported the occurrence of female dominancy over male in various species of Clupeiform under different environmental conditions. Tsikliras et al. (2010) reported a female-biased sex ratio in $72 \%$ of the fish species due to an adaptive strategy to boost the egg numbers to promote the recruitment of
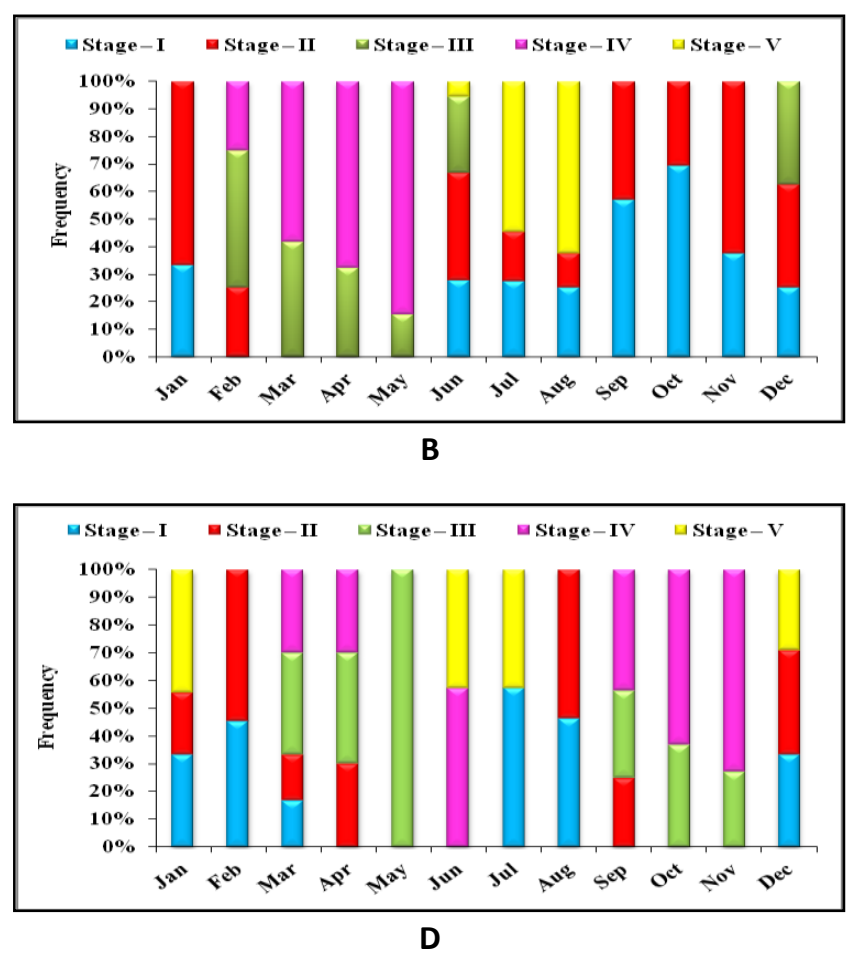

more offspring (García-Abad et al., 1998). The female biased population of the fish could be due to the differentiation in growth, longevity and mortality rate between the sexes or the energy costs of reproduction (Potts \& Wootton, 1984; Marshall et al., 1998; Vicentini \& Araujo, 2003; Zhang et al., 2009; Mahmood et al., 2011). The biased sex ratio may be because of ecological factors (Gamble \& Zarkower, 2012), abundancy of forage items or reproductive behaviour (Marshall et al., 1998; Vicentini \& Arau'jo, 2003; Mahmood et al., 2011; Vandeputte et al., 2012). Zhang et al. (2009) also pointed out the factors such as growth rate, sex reversal and migration for biased sex ratio in different species of the fish. However, in the present study, amphidromous and potamodromous migration may be the reason for the biased sex ratio in the fish population. 


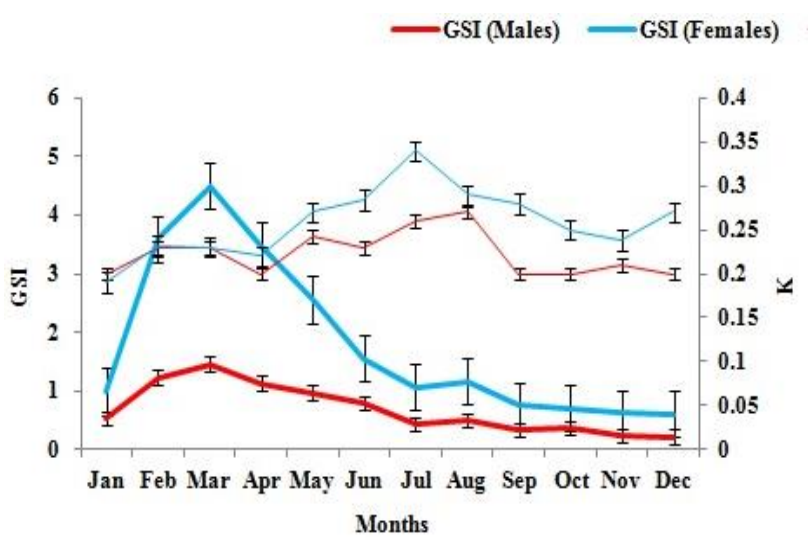

(A)

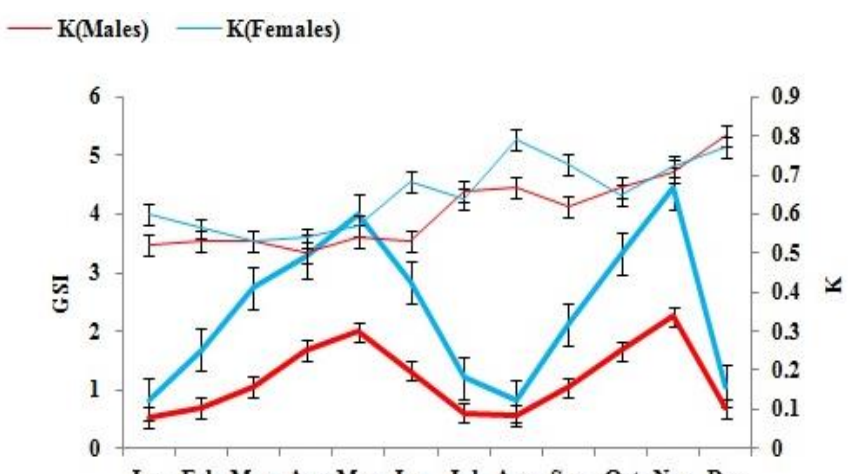

Jan Feb Mar Apr May Jun Jul Aug Sep Oct Nov Dec

Months

(B)

Figure 3. Mean \pm SD of the gonadosomatic index (GSI) and condition factor (K) of males and females in S. phasa of river Ganga (A) and Hooghly estuary (B).

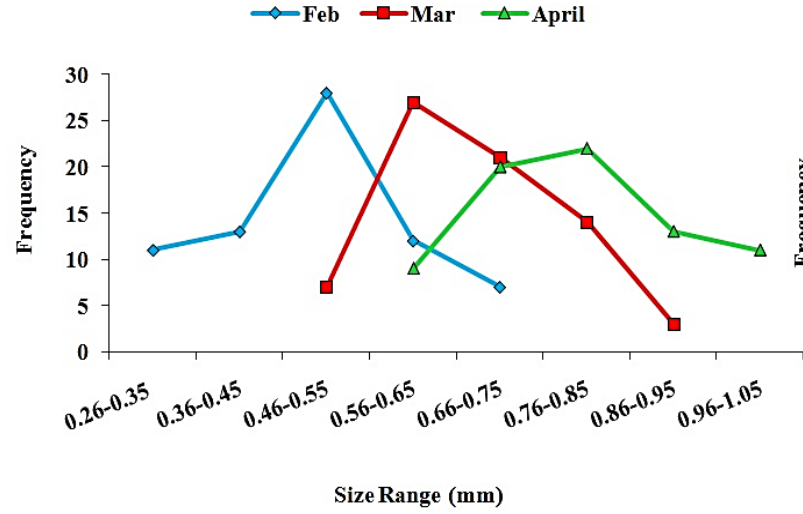

(A)

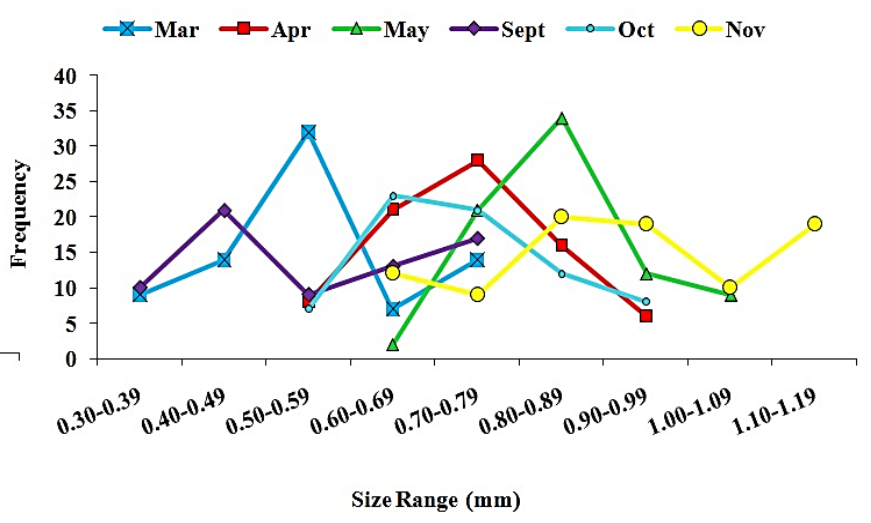

(B)

Figure 4. Size Frequency distribution of intraovarian oocytes of S. phasa collected from river Ganga (A) and Hooghly estuary (B).

Table 3 Regression analyses of relative fecundities in S. phasa collected from river Ganga and Hooghly estuary.

\begin{tabular}{|c|c|c|c|c|c|}
\hline \multicolumn{3}{|c|}{ Ganga River } & \multicolumn{3}{|c|}{ Hooghly Estuary } \\
\hline Parameters & Regression equations & $\mathrm{R}^{2}$ & Regression equations & $\mathrm{R}^{2}$ & $\mathrm{P}$ \\
\hline TL vs F & $\log F=2.2182+0.8937 \log T L$ & 0.9826 & $\log F=3.10+0.8010 \log T L$ & 0.9740 & $0.0001^{*}$ \\
\hline$B W$ vs $F$ & $\log F=2.5493+0.8765 \log B W$ & 0.9639 & $\log F=2.534+0.8321 \log B W$ & 0.9621 & $0.0219 *$ \\
\hline OL vs F & $\log F=2.8067+1.9406 \log O L$ & 0.9652 & $\log F=2.6032+1.356 \log O L$ & 0.9640 & $0.9264 \mathrm{~ns}$ \\
\hline OW vs F & Log $F=3.2161+1.2958 \log O W$ & 0.9730 & $\log F=3.12+0.456 \log O W$ & 0.9681 & $0.0057^{*}$ \\
\hline
\end{tabular}

$\mathrm{F}=$ fecundity, $\mathrm{TL}=$ total length, $\mathrm{BW}=$ eviscerated body weight, $\mathrm{OL}=$ ovary length and $\mathrm{OW}=$ ovary weight, $\mathrm{R}^{2}=$ correlation coefficient

Note. ns: not significant

$\mathrm{P}=$ *Significant values at the $5 \%$ level

The large and healthy individuals of female fish are less vulnerable for predation and generate maximum number of high-quality gametes because of more energy stores in their muscle and liver for the growth and development of their gametes (Helfman et al., 1987; Jonsson \& Jonsson, 2015). The occurrence of larger and heavier females of $S$. phasa in the present study was found to be in corroboration with other clupeids (Kabir et al., 1998; Lopes et al., 2018), although the sex ratio at size varies temporally and spatially according to Arocha and Barrios (2009).

Five maturity stages were recorded during the present study after following the scheme of classification given by Brown-Peterson et al. (2011). But,
Jhingran (1961) recognized seven stages of maturity in S. phasa after following the scheme as given by Hjort (1911). In the specimens of the fish of Ganga River, the high value of GSI was recorded in both sexes during the period from February to April because of the full development of gonads. Recovering gonads remained quiescent from September through January in the fish of river Ganga. An increase in the development of gonads took place during February/March, followed thereafter, by rapid changes in gonads. The peak condition of the development of gonads in the fish of river was recorded during March. However, in Hooghly estuary, two peaks were observed in a year in both the sexes of $S$. phasa which coincided with the rainy and post rainy seasons. 
In the specimens of Hooghly estuary, high GSI in both sexes were observed during May and November which represents full development of gonads during these months. However, it is relevant to mention that according to Mookerjee and Mookerjee (1950) clupeids breed in the tidal areas during the periods from January through July, while Jones and Menon (1952) reported the peak breeding period of S. phasa during OctoberNovember on the basis of the collected developing eggs, larvae and juveniles from Hooghly estuary near Barrackpore. According to the present study, S. phasa breeds more than once in a year in Hooghly estuary and once in river Ganga at Allahabad-Varanasi region. A survey of literature showed that, in tropical and subtropical regions, clupeids reproduce throughout the year (Wootton \& Smith, 2015). Kabir et al. (1998) and Almukhtar et al. (2016) also recorded the two spawning peaks in Gadusia chapra and Tenualosa ilisha respectively. The breeding process has a direct relation with the onset and duration of monsoon and flooding cycles (Sarkar et al., 2010), perhaps this is the reason why the breeding season in most fishes is not the same in different regions of the country. In the present study, the sampling sites of $S$. phasa are located in tropical region where well-defined seasonal variations do occur, and the difference in the spawning period might be related to variations in the environmental conditions. $A$ lot of notable researchers like Sarkar et al. (2018, 2019), Karnatak et al. $(2018,2020)$ established the correlation between GSI and climate variables and emphasized that climatic variability particularly temperature and seasonal rainfall was considered to be important for the regulation of the reproductive cycles in the teleostean fish which may lead the region-specific changes in breeding phenology.

The GSI values and condition factor indicated no direct relation in S. phasa of both the ecosystems. Similar to this study, Cardoso et al. (2019) reported the opposite pattern for mean condition factor (K) and GSI. The high absolute fecundity was recorded in S. phasa of Ganga River as compared to those living in estuary. Guèye et al. (2012) pointed out that the efficiency of foraging of fish species and prey availability influence the condition and reproductive potential in fish. Variation in the number of eggs produced by the individual fish is generally dependent on the factors like overexploitation, habitat degradation, unsustainable harvesting, food availability, size, age and condition of the particular species (Bhuiyan et al., 2006; Sarkar et al., 2012b; Gupta et al., 2014). Several researchers (Sarkar et al., 2009, 2012b) reported that factors such as time of sampling, maturation stage and nutritional status affect the fecundity between fish populations.

In the present study, fish collected from estuary have low absolute fecundity and high ova diameter while the fish of river Ganga showed high absolute fecundity and low ova diameter. Several researchers pointed out that the intraspecific discrepancy in mean egg dimension may likely owing to variation in intimacy and population density of spawner or due to specific ovulation time and the stage of egg development (Ezenwa, 1981) and could also because of water turbulence in defined ecosystems (Denny \& Shibata, 1989; Levitan \& Petersen, 1995). Smith and Fretwell (1974) and Einum and Fleming (2004) documented that mean increase in egg size and decrease in egg number may occur because of environmental variability and its quality. Lahti and Muje (1991) reported that eggs of large size with a relatively small number are an adaptation to the poor food supply for the juveniles. The variations in relation between fecundity and ova diameter were due to the differences in individual ovulation time, stage of egg development and abiotic factors (Ezenwa, 1981; De Silva, 1986; Legendre \& Ecoutin, 1989). Guèye et al. (2012) also established the trade-off between fecundity and egg size in fish.

Significant variations were recorded in the reproductive traits (fecundity, oocyte diameter, condition factor, GSI) between two populations of $S$. phasa collected from two different ecosystems viz. freshwater and estuarine. The present study corroborated with the earlier study of Gueye et al. (2012) who reported the significant variations in the reproductive traits (fecundity, oocyte diameter, oocyte weight, condition factor, GSI) of females black chinned tilapia collected from three different ecosystems (coastal marine, freshwater and estuarine). A lot of previous studies (Gueye et al., 2012; Sarkar et al., 2017; Praveen et al., 2017) have also reported the intraspecific differences in reproductive traits (fecundity, oocyte diameter, condition factor, GSI) between the populations of the fish and emphasized that these variations reflect the adaptation of fish to the local environmental conditions (Taylor, 1991; Conover \& Schultz, 1997; Sarkar et al., 2017; Praveen et al., 2017).

A linear relationship was found to exist between fecundity and each one of these four parameters (TL, BW and $\mathrm{OW}$ and $\mathrm{OL}$ ). The fecundity was better correlated with TL followed by BW, OW and OL. Similar, results were reported by other researchers (Sarkar et al., 2009; Mir et al., 2013; Gupta et al., 2014; Kashyap et al., 2016; Faridi et al., 2020) in different fish species.

\section{Conclusion}

The intraspecific variations in reproductive traits reflect the environmentally induced reproductive plasticity in the fish. The study of the reproductive cycle and fecundity is essential and fundamental for understanding the fish population dynamics to obtain a sustainable harvesting. The baseline data on the reproductive biology of little known species are helpful for the development of stock assessment models, which can be utilized further for effectively scientific sustainable management of natural population of the overexploited fish or degraded habitats. Moreover, the knowledge of reproductive biology of the fish is considered to be important and helpful for adequate 
implementation of management measures in restoring the depleted stocks of the fish species because ambiguity in species biology could hinder accurate stock assessment and monitoring.

\section{Ethical Statement}

This study does not need any formal consent as the experimental fish, Setipinna phasa is widely distributed in the river Ganga at Allahabad-Varanasi region and Hooghly estuary. The collection sites were not restricted areas but fishing is carried out commercially. The species is designated as 'least concern' by IUCN's Red List of threatened species. The study complies with the existing rules and guidelines outlined by the Committee for the Purpose of Control and Supervision of Experiments on Animals (CPCSEA), guidelines for laboratory animal facility, Government of India.

\section{Acknowledgements}

The authors thank the Head, Department of Zoology, University of Lucknow for providing facility and administrative support. F.B. is thankful to the University Grants Commission (UGC), New Delhi for the senior research fellowship [Ref No-19/06/2016(i) EU-V].

\section{References}

Abbas, N., \& Subramanian, V. (1984). Erosion and sediment transport in the Ganges river basin (India). Journal of Hydrology, 69,173-182. https://doi.org/10.1016/00221694(84)90162-8

Afonso-Dias, I., Reis, C., \& Andrade, J.P. (2005). Reproductive aspects of Microchirus azevia (Risso, 1810) (Pisces: Soleidae) from the south coast of Portuga. Scientia Marina, 69, 275-283. https://doi.org/10.3989/scimar.2005.69n2275

Almukhtar, M.A., Jasim, W., \& Mutlak, F. (2016). Reproductive Biology of Hilsa Shad Tenualosa ilisha (Teleostei: Clupeidae) During Spawning Migration in the Shatt Al Arab River and Southern Al Hammar Marsh, Basra, Iraq. Journal of Fisheries and Aquatic Science, 11, 43-55. https://doi.org/10.3923/jfas.2016

Arocha, F., \& Barrios, A. (2009). Sex ratios, spawning seasonality, sexual maturity and fecundity of white marlin (Tetrapturus albidus) from the Western Central Atlantic. Fisheries Research, 95, 98-111. https://doi.org/10.1016/j.fishres.2008.08.010

Begg, G.A. (1998). Reproductive biology of school mackerel (Scomberomorus queenslandicus) and spotted mackerel (S. munroi) in Queensland east-coast waters. Marine Freshwater Research, 49, 261-270. https://doi.org/10.1071/MF97187

Bhuiyan, A.S., Afroz, S., \& Zaman, T. (2006). Food and feeding habit of the juvenile and adult snakehead, Channa punctatus (Bloch). Journal of Life and Earth Science, 1, 53-54.

Blanck, A., \& Lamouroux, N. (2007). Large-scale intraspecific variation in life-history traits of European freshwater fish. Journal of Biogeography, 34, 862-875. https://doi.org/10.1111/j.1365-2699.2006.01654.x
Brown-Peterson, N.J., Wyanski, D.M., Saborido-Rey, F., Macewicz, B.J., \& Lowerre-Barbieri, S.K. (2011). A standardized terminology for describing reproductive development in fishes. Marine and Coastal Fisheries: Dynamics, Management, and Ecosystem Science, 3, 5270. https://doi.org/10.1080/19425120.2011.555724

Cao, L., Song, B., Zha, J., Yang, C., Gong, X., Li, J., \& Wang, W. (2009). Age composition, growth, and reproductive biology of yellow catfish (Peltobagrus fulvidraco, Bagridae) in Ce Lake of Hubei Province, Central China. Environmental Biology of Fishes, 86, 75-88. https://doi.org/10.1007/978-90-481-3458-8_12

Cardoso, R.D.L., Silva, M.H.L., Carvalho-Neta, R.N.F., Castro, A.C.L.D., Ferreira, C.F.C., Ferreira, H.R.S., \& Santos, D.M.S. (2019). Aspects of reproductive biology of curimba Prochilodus lacustris (Pisces, Prochilodontidae) in a tropical lake in Northeastern Brazil. Journal of Applied Ichthyology, 35, 488-500. https://doi.org/10.1111/jai.13868

Clark, F.N. (1934). Maturity of the California sardine (Sardina cacrulea) determined by ova diameter measurements. California Department of Fish and Game, 42, 1-49.

Conover, D.O., \& Schultz, E.T. (1997). Natural selection and evolution of the growth rate in the early life history: what are the trades offs? In R.C. Chambers and E.A. Trippel, (eds.), Early Life History and Recruitments in Fish Populations (305-332pp). Chapman and Hall, New York.

Corrêa, E.D., Chaves, P.T., \& Guimarães, P.R.B. (2005). Biology of Chirocentrodon bleekerianus (Poey, 1867) (Clupeiformes: Pristigasteridae) in a continental shelf region of southern Brazil. Brazilian Archives of Biology and Technology, 48, 419-427.

http://dx.doi.org/10.1590/S1516-89132005000300013

De Carvalho, P.A., Paschoalini, A.L., Santos, G.B., Rizzo, E., \& Bazzoli, N. (2009). Reproductive biology of Astyanax fasciatus (Pisces: Characiformes) in a reservoir in south eastern Brazil. Journal of Applied Ichthyology, 25, 306313. https://doi.org/10.1111/j.1439-0426.2009.01238.x

De Silva, S.S. (1986). Reproductive biology of Oreochromis mossabicus populations of man-made lakes in Sri Lanka: a comparative study. Aquaculture and Fisheries Management, 17, 31-38. https://doi.org/10.1111/j.1365-2109.1986.tb00083.x

Denny, M.W., \& Shibata, M.F. (1989). Consequences of surf zone turbulence for settlement and external fertilization. The American Naturalist, 134, 859-889.

Deshmukh, A.V., Kovale, S.R., Sawant, M.S., Shirdnankar, M.M., \& Funde, A.B. (2010). Reproductive biology of Sardinella longiceps along Ratnagiri coast off Maharashtra. Indian Journal of Marine Sciences, 39, 274279. http://hdl.handle.net/123456789/10023

Doha, H. (1970). Fecundity of Padma river hilsa, Hilsa ilisha (Ham.). Pakistan Journal of Science, 22, 176-184.

Einum, S., \& Fleming, I.A. (2004). Environmental unpredictability and offspring size: conservative versus diversified bethedging. Evolutionary Ecology Research, 6, 443-455.

Eyo, V.O., Ekanem, A.P., \& Jimmy, U.U. (2014). A comparative study of the gonado-somatic index (GSI) and gonad gross morphology of African catfish (Clarias gariepinus) fed unical aqua feed and coppens commercial feed. Croatian Journal of Fisheries, 72, 52-66. https://doi.org/10.14798/72.2.706

Ezenwa, B. (1981). A study of the reproductive biology of the catfish, Chrysichthys nigro digitatus (Lacépède) in 
Nigeria. [Ph.D. thesis, University of Lagos, Nigeria], 178.

Faridi, A.A., Bano, A., \& Serajuddin, M. Aspects of reproductive biology of the lesser spiny eel Macrognathus aculeatus (Bloch, 1786) from river Ganga, Uttar Pradesh, India. Indian Journal of Fisheries, 67, 15-22, 2020. https://doi.org/10.21077/ijf.2019.67.2.94362-03

Fontoura, N.F., Braun, A.S., \& Milani, P.C.C. (2009). Estimating size at first maturity (L50) from gonadosomatic index (GSI) data. Neotropical Ichthyology, 7, 217-222. https://doi.org/10.1590/S1679-62252009000200013

Froese, R. (2004). Keep it simple: three indicators to deal with overfishing. Fish and Fisheries, 5, 8691. https://doi.org/10.1111/j.1467-2979.2004.00144.x

Gamble, T., \& Zarkower, D. (2012). Sex determination. Current Biology, 22, 275-262. http://dx.doi.org/10.1016/j.cub.2012.02.054.

Gangan, S.S., Jaiswar A.K., Pavan-Kumar A., Jahageerdar S., Lakra W.S., \& Krishna G. (2018a). A report on anomalies in pelvic fin and pectoral filament of two species of genus Setipinna (Swainson, 1839) from east of India. Indian Journal of Geo Marine Sciences, 47, 1893-1898. http://nopr.niscair.res.in/handle/123456789/44906

Gangan, S.S., Kumar, R., Ramteke, K.K., Kumar, A.P., \& Jaiswar, A.K. (2016). Study of morphological variation discernible by multivariate analysis between the species of genus Setipinna (Teleostei: Clupeiformes). Ecology Environment Conservation, 22, S11-S16.

Gangan, S.S., Pavan-Kumar, A., Bamaniya, D., Jahageerdar, S., Lakra, W.S., \& Jaiswar, A.K. (2018b). A Report on Ecotypes of Setipinna phasa (Hamilton-Buchanan, 1822) from Indian Waters. Turkish Journal of Fisheries and Aquatic Sciences, 18, 729-738.

http://dx.doi.org/10.4194/1303-2712-v18_5_08.

García-Abad, M.C., Yáñez-Arancibia, A., Sánchesgil, P., \& TapiaGarcía, M. (1998). Distribution, abundance and reproduction of Opisthonema oglinum (Pisces: Clupeidae) on the continental shelf of the southern Gulf of Mexico. Revista de Biología Tropical, 46, 257-266. http://www.scielo.sa.cr/scielo.php?script=sci_arttext\& pid=S003477441998000200010\&Ing=en\&tIng=es.

Guèye, M., Tine, M., Kantoussan, J., Ndiaye, P., \& Thiaw, O.T. (2012). Comparative Analysis of Reproductive Traits in Black-Chinned Tilapia Females from Various Coastal Marine, Estuarine and Freshwater Ecosystems. PLOS ONE, 7, Article e29464.

https://doi.org/10.1371/journal.pone.0029464

Gupta, B.K., Sarkar, U.K., \& Bhradwaj, S.K. (2014). Reproductive biology of Indian Silurid catfish Ompok pabda in river Gomti. Journal of Environmental Biology, 35, 345-351.

http://www.jeb.co.in/journal_issues/201403_mar14/pa per_07.pdf

Helfman, G.S., Facey, D.E., Hales, L.S.J., \& Bozeman, E.L.J. (1987). Reproductive ecology of the American eel. In: M.J. Dadswell, R.J. Klauda, C.M. Moffitt, R.L. Saunders, R.A. Rulifson and J.E. Cooper, eds. Common strategies of anadromous and catadromous fishes. Bethesda: American Fisheries Society, 1, 42-56.

Hjort, J. (1911). State of the sexual organs in the herring. Cons. Prem. Internat. P. L Explor. de la Mer. Pub. de Cirons 53.

IUCN (2010). International Union for Conservation of Nature and Natural Resources. www.iucnredlist.

Jhingran, A.G. (1961). Studies on the maturity and fecundity of Gangetic anchovy, S. phasa (Ham.). Indian Journal of Fisheries, 8, 291-311.
Jones, S., \& Menon, P.M.G. (1952). Observations on the life history, bionomics and fishery of the gangetic anchovy, Setipinna phasa (Hamilton). Journal of Zoological Society of India, 3, 323-333.

Jonsson, B., \& Jonsson, N. (2015). Sexual size dimorphism in anadromous brown trout Salmo trutta. Journal of Fish Biology, 87, 187-193. PMid: 25959597. https://doi.org/10.1111/jfb.12704

Kabir, A.K.M.A., Hossain, M.A., Rahmatullah, S.M., Dewan, S., \& Islam, M.S. (1998). Studies on the gonadosomatic index and fecundity of chapila (Gudusia chapra Ham.). Bangladesh. Journal of Fisheries Research, 2, 195-200. http://aquaticcommons.org/16405/1/BJFR2.2_195.pdf

Kamanga, L.J., Kaunda, E., Mtimuni, J.P., Maluwa, A., \& Mfitilodze, W.M. (2002). Effect of temperature on gonadosomatic index (GSI) of Oreochromis karongae (Trewavas). Aqua-Fish Technical Report, 1, 21-24. http://aquaticcommons.org/1385/1/AquaFish_1_(2124).pdf

Karnatak, G., Sarkar, U.K., Naskar, M., Roy, K., Gupta, S., Nandy, S.K., Srivastava, P.K., Sarkar, S.D., Sudheesan, D., Bose, A.K., \& Verma, V.K. (2018). Understanding role of climatic and environmental parameters in gonadal maturation and spawning periodicity of spotted snakehead, Channa punctata (Bloch, 1793) in a tropical floodplain wetland, India. Environmental Biology of Fishes, 101, 595-607. https://doi.org/10. 1007/s10641018-0722-6

Karnatak, G., Sarkar, U.K., Naskar, M., Roy, K., Nandi, S., Mishal, P., Lianthuamluaia, L., Kumari, S., \& Das, B.K. (2020). Modeling pre-spawning fitness and optimal climate of spotted snakehead Channa punctata (Bloch, 1793) from a Gangetic floodplain wetland of West Bengal, India. International Journal of Biometeorology, pp. 1-10.

Kashyap, A., Awasthi, M., \& Serajuddin, M. (2016). Reproductive biology of the freshwater murrel Channa punctatus (Bloch, 1793) from River Gomti of Lucknow region, Uttar Pradesh, India. Indian Journal of Fisheries, 63, 126-130.

Lahti, E., \& Muje, P. (1991). Egg quality and female condition in vendace (Coregonus albda L.) before and during spawning. Hydrobiologia, 209, 175-182. https://doi.org/10.1007/BF00015340

Legendre, M., \& Ecoutin, J.M. (1996). Aspects of the reproductive strategy of Sarotherodon melanotheron: comparison between a natural population ( $E^{\prime}$ brie' lagoon, Co^te d'Ivoire) and different cultured populations. In: Pullin RSV, Lazard J, Legendre M, Amon Kothias J;-B, Pauly D, eds. Proceeding of the 3rd international symposium on Tilapia in aquaculture ICLARM, Manila. pp 320-325.

Levitan, D.R., \& Petersen, C. (1995). Sperm limitation in the sea. Trends in Ecology Evolution, 10, 228-231.

Lopes, C.A., Reynalte-Tatajec, D.A., \& Nuñera, A.P.O. (2018). Reproductive dynamics of Lycengraulis grossidens (Clupeiformes: Engraulidae) and Platanichthys platana (Clupeiformes: Clupeidae) in a subtropical coastal lagoon. Brazilian Journal of Biology, 78, 477- 486. http://dx. doi.org/10.1590/1519-6984.170155.

Mahmood, K., Ayub, Z., \& Siddiqui, G. (2011). Sex-ratio, maturation and spawning of the Indian Ilisha, Ilisha melasstoma (Clupeiformes: Pristigasteridae) in coastal waters of Pakistan (northern Arabian Sea). Indian Journal of Geo-Marine Sciences, 40, 516-521. 
http://hdl.handle.net/123456789/12764

Marshall, C.T., Kjesbu, O.S., Yaragina, N.A., Solemdal, P., \& Ulltang, O. (1998). Is spawner biomass a sensitive measure of the reproductive and recruitment potential of northeast Arctic cod? Canadian Journal of Fisheries and Aquatic Sciences, 55, 1766-1783. https://doi.org/10.1139/f98-062

Marshall, C.T., Needle, C.L., Thorsen, A., Kjesbu, O.S., \& Yaragina, N.A. (2006). Systematic bias in estimates of reproductive potential of an Atlantic cod (Gadus morhua) stock: implications for stockrecruit theory and management. Canadian Journal of Fisheries and Aquatic Sciences, 63, 980-994. https://doi.org/10.1139/f05-270

Mir, J.I., Sarkar, U.K., Dwivedi, A.K., Gusain, O.P., \& Jena, J.K. (2013). Comparative pattern of reproductive traits in Labeo rohita (Hamilton 1822) from six tropical rivers of Ganges Basin: a new insight. The Proceedings of the National Academy of Sciences, India, Section B: Biological Sciences, 84, 91-103. https://doi.org/10.1007/s40011-013-0181-y

Mookerjee, H.K., \& Mookerjee, P.S. (1950). On some aspects of the natural history of Engraulis hamiltonii and Engranlis telara. Proc. 37th Indian Sd. Congr., Part III, Abstracts: p. 251.

Morgan, M.J. (2008). Integrating reproductive biology into scientific advice for fisheries management. Journal of the Northwest Atlantic Fisheries Science, 41, 37-51. doi:10.2960/J. v41.m615

Murua, H., Kraus, G., Saborido Rey, F., Witthames, A.R., Thorsen, P., \& Junquera, V. (2003). Procedures to estimate fecundity of marine fish species in relation to their reproductive strategy. Journal of Northwest Atlantic Fishery Science, 33, 33-54. http://eprints.unikiel.de/2615/1/murua2.pdf

Nash, R.D.M., Valencia, A.H., \& Geffen, A.J. (2006). The Origin of Fulton's Condition Factor - Setting the Record Straight. Fisheries, 31, 236-238.

https://folk.uib.no/nfiag/nfiag/reprints/NashETAL2006F isheries.pdf

Nikolsky, G.V. (1963). The ecology of fishes. Academic, London, 233p.

Page, L.M. (1974). The life history of the spottail darter, Etheostoma squamiceps, in Big Creek, Illinois, and Ferguson Creek, Kentucky. Biological notes, 089.

Potts, G.W., \& Wootton, R.J. (1984). Fish Reproduction Strategies and Tactics. Academic, London, United Kingdom.

Prasad, L., Dwivedi, A.K., Dubey, V.K., \& Serajuddin, M. (2011). Reproductive biology of freshwater murrel, Channa punctatus (Bloch, 1793) from river Varuna (a tributary of Ganga River) in India. Journal of Ecophysiology and Occupational Health, 11, 69-80.

Praveen, A., Uttam Kumar, S., Naresh Sahebrao, N., Rahsya Mani, M., Ravindra, K., Abhishek, A., \& Brijesh Kumar, P. (2017). Dynamics of reproductive ecology of the fish Ompok bimaculatus (Siluriformes: Siluridae) in six tropical rivers of the Ganges basin, India. Cuadernos de Investigación UNED, 9(1), 73-85.

Reddy, P.B. (1979). Maturity and spawning in the murrel, Channa punctata (Bloch, 1973) (Pisces, Teleostei, Channidae) from Guntur, Andhra Pradesh. Proceedings of Indian National Science Academy, 45, 543-553.

Roomiani, L., Sotudeh, A.M., \& Hakimi Mofrad, R. (2014). Reproductive biology of Hilsa shad (Tenualosa ilisha) in coastal Waters of the Northwest of Persian Gulf. Iranian
Journal of Fisheries Sciences, 13, 201-215. http://jifro.ir/article-1-1439-en.html

Sadhuram, Y., Sarma, V.V., Ramana Murthy, T.V., \& Prabhakar, R.B. (2005). Seasonal variability of the physicochemical characteristics of the Haldia channel Hooghly Estuary. Journal of Earth System Science, 114, 37-49. https://doi.org/10.1007/BF02702007

Saigal, B.N., Mitra, P.M., \& Karmarkar, H.C. (1987). Migratory winter bag-net fishery in coastal waters of the Hooghly estuary. Bulletin National Symposium on Research and Development in Marine Fisheries Sessions I \& II, CMFRI, Kochi, 44, 94-101.

http://eprints.cmfri.org.in/id/eprint/2843

Sarkar, U.K., Deepak, P.K., \& Lakra, W.S. (2009). Stock identification of endangered clown knife fish Chitala chitala (Hamilton-Buchanan, 1822) from Indian rivers inferred by morphological attribute. Electronic Journal of Ichthyology, 2, 59-75.

http://krishi.icar.gov.in/jspui/handle/123456789/5019

Sarkar, U.K., Gupta, B.K., \& Lakra, W.S. (2010). Biodiversity, eco-hydrology, threat status and conservation priority of the freshwater fishes of river Gomti, a tributary of river Ganga. The Environmentalist, 30, 3-17. https://doi.org/10.1007/s10669-009-9237-1

Sarkar, U.K., Pathak, A.K., Sinha, R.K., Sivakumar, R., Pandian, A.K., Pandey, A., Dubey, V.K., \& Lakra, W.S. (2012a). Freshwater fish biodiversity in the river Ganga (India): changing pattern, threats and conservation perspectives. Review in Fish Biology and Fisheries, 22, 251-272. https://doi.org/10.1007/s11160-011-9218-6

Sarkar, U.K., Kumar, R.S., Dubey, V.K., Pandey, A., \& Lakra, W.S. (2012b). Population structure and reproductive biology of a freshwater fish, Labeo boggut (Sykes, 1839), from two perennial rivers of Yamuna basin. Journal of Applied Ichthyology, 28, 107-115. doi: 10.1111/j.14390426.2011. 01902.x

Sarkar, U.K., Agnihotri, P., Kumar, R., Awasthi, A., Pandey, B.K., \& Mishra, A. (2017). Dynamics of inter-population reproductive pattern in butter catfish, Ompok bimaculatus (Bloch, 1794) from different rivers in India. Turkish Journal of Fisheries and Aquatic Sciences, 17(5), 1063-1073. https://doi.org 10.4194/1303-2712-v17_5_23

Sarkar, U.K., Naskar, M., Roy, K., Sudheesan, D., Gupta, S., Bose, A.K., Srivastava, P.K., Nandy, S.K., Verma, V.K., Sarkar, S.D., \& Karnatak, G. (2018). Baseline information of reproduction parameters of an amphidromous croaker Johnius coitor (Hamilton, 1822) from Ganga River Basin, India with special reference to potential influence of climatic variability. Aquatic Living Resources, 31, 1-12. doi: https://doi.org/10.1051/Alr/2017042.

Sarkar, U.K., Naskar, M., Srivastava, P.K., Roy, K., Sarkar, S.D., Gupta, S., Bose, A.K., Nandy, S.K., Verma, V.K., Sudheesan, D., \& Karnatak, G. (2019). Climatoenvironmental influence on breeding phenology of native catfishes in River Ganga and modeling species response to climatic variability for their conservation. International journal of biometeorology, 63, 991-1004. doi: https://doi.org/10.1007/s00484-01901703-3

Smith, C.C., \& Fretwell, S.D. (1974). The optimal balance between size and number of offspring. American Naturalist, 108, 499-506.

Taylor, E.B. (1991). A review of local adaptation in Salmonidae, with particular reference to pacific and Atlantic salmon. 
Aquaculture, 98, 185-208.

Tsikliras, A.C., \& Koutrakis, E.T. (2013). Growth and reproduction of European sardine, Sardina pilchardus (Pisces: Clupeidae), in northeastern Mediterranean. Cahiers de Biologie Marine, 54, 365-374.

Tsikliras, A.S., Antonopoulou, E., \& Stergiou, K.I. (2010). Spawning period of Mediterranean marine fishes. Reviews in Fish Biology and Fisheries, 20, 499-538. https://doi.org/10.1007/s11160-010-9158-6

Vandeputte, M., Quillet, E., \& Chatain, B. (2012). Are sex ratios in wild European sea bass (Dicentrarchus labrax) populations biased? Aquatic Living Resources, 25, 77-81. https://doi.org/10.1051/alr/2012002

Vicentini, R.N., \& Arau'jo, F.G. (2003). Sex ratio and size structure of Micropogonias furnieri (Desmarest, 1823) (Perciformes, Sciaenidae) in Sepetiba Bay, Rio de Janeiro, Brazil. Brazilian Journal of Biology, 63, 559-566. https://doi.org/10.1590/S1519-69842003000400003

Whitehead, P.J.P. (1972). A synopsis of the clupeoid fishes of India. Journal of marine biological Association of India,
14, 160-256.

Whitehead, P.J.P., Nelson, G.J., \& Wongratana, T. (1988). FAO species catalogue: Clupeiod fishes of the world. An annotated and illustrated catalogue of the herrings, sardines, pilchards, sprats, shad, anchovies and wolf herring. Engraulidae (Part 2) FAO, Fish Synopsis, 7, 125.

Winn, H.E. (1958a). Observations on the reproductive habits of darters (Pisces-Percidae). American Midland Naturalist, 59(1), 190-212.

Winn, H.E. (1958b). Comparative reproductive behavior and ecology of fourteen species of darters (Pisces-Percidaei). Ecological Monographs, 28(21), 155-191.

Wootton, R.J., \& Smith, C. (2015). Reproductive Biology of Teleost Fishes. John Wiley \& Sons, Oxford, UK.

Zhang, J., Takita, T., \& Zhang, C., (2009). Reproductive biology of Ilisha elongata (Teleostei: Pristigasteridae) in Ariake Sound, Japan: Implications for estuarine fish conservation in Asia. Estuarine, Coastal and Shelf Science, 81, 105-113. https://doi.org/10.1016/j.ecss.2008.10.013 